\title{
Statistical analysis of urban regional pre-monsoon rainfall in and around Kolkata, India
}

\author{
Sweta Chakraborty ${ }^{1,2,3, *}$, Biswajit Roy Chowdhury ${ }^{4}$, Sarbari Ghosh ${ }^{1,3,5}$, \\ $\mathrm{P} \mathrm{K} \mathrm{SEN}^{6}$ and $\mathrm{U} \mathrm{K} \mathrm{DE}^{3}$ \\ ${ }^{1}$ Department of Atmospheric Sciences, University of Calcutta, Kolkata, India. \\ ${ }^{2}$ Jagadis Bose National Science Talent Search, Kolkata, India. \\ ${ }^{3}$ Centre for Interdisciplinary Research and Education, Kolkata, India. \\ ${ }^{4}$ Department of Geography, Vidyasagar College, Kolkata, India. \\ ${ }^{5}$ Department of Mathematics, Vidyasagar Evening College, Kolkata, India. \\ ${ }^{6}$ Department of Mathematics, Jadavpur University, Kolkata, India. \\ *Corresponding author.e-mail: sweta.chakraborty23@gmail.com
}

MS received 16 October 2017; accepted 30 May 2018; published online 25 February 2019

The present study aims at statistical analysis of pre-monsoon rainfall at Kolkata, India over a span of 45 yr (1970-2014) with special emphasis on the effect of urbanisation on pre-monsoon rainfall at Alipore, a core area of Kolkata $\left(22^{\circ} 34^{\prime} \mathrm{N} ; 88^{\circ} 24^{\prime} \mathrm{E}\right)$ India, where the urbanisation is almost static during the period 1970-2014 and Dumdum $\left(22^{\circ} 65^{\prime} \mathrm{N} ; 88^{\circ} 45^{\prime} \mathrm{E}\right)$, the outer periphery of Kolkata, where the urbanisation is still an ongoing process. As pre-monsoon rainfall is an effect of mesoscale convective development (horizontal dimensions 5-500 km), the two stations namely Dumdum and Alipore which are nearly $22 \mathrm{~km}$ apart from each other are taken into consideration in this study. To determine the possible changes in the pre-monsoon rainfall in both stations, a non-parametric Wilcoxon Signed Rank Sum test is conducted. This test reveals that the annual average pre-monsoon rainfall increased at Dumdum in post-urbanisation period, i.e., 1991-2014 compared to Alipore during the same period. It is important to note that the result of statistical analysis almost tallies with that of the geographical one.

Keywords. Urbanisation; pre-monsoon rainfall; Wilcoxon Signed Rank Sum test; land-use change; rainfall trends.

\section{Introduction}

Variability in rainfall pattern is one of the important factors in climatology of an area. Rainfall plays a key role in socio-economic development of any region. Rainfall variation affects freshwater availability and food production at sahel (Dore 2005). Studies were conducted on the precipitation variability all over the world. The results show increased precipitation in northern hemisphere and reduction in precipitation in China, Australia and pacific small islands. Sahu and Khare (2015) concluded that the precipitation should be quantified as a mesoscale system as all the districts in Odisha do not experience equal amount of rainfall and have localised intensity. According to New et al. (2001), precipitation is the most variable global parameter. Kumar et al. (1997) studied the maximum and minimum temperatures in the premonsoon months and its relation with upcoming monsoon in India. A stepwise regression model involving three predictors was used for long-range 
forecasting of all India summer monsoon rainfall in this study. Annual, seasonal and monthly rainfall variability in India was studied by Kumar et al. (2010). They found increased rainfall in premonsoon, post-monsoon and winter months.

The precipitation in pre-monsoon season (March, April and May) of West Bengal comes from thunderstorm activities. This contributes to nearly $15 \%$ of annual rainfall. In Gangetic West Bengal more than $50 \%$ of thunderstorm activity comes from Nor'wester, which occurs because of collision of two different air masses, i.e., hot, dry air mass coming from the northwest and comparatively colder, moist air mass coming from the Bay of Bengal. On mixing, the buoyant air mass goes up and becomes saturated with moisture in the presence of a suitable triggering effect (Chatterjee et al. 2008). Pre-monsoon season is synonymous with heat and humidity with uncomfortable conditions throughout the day and night. Clouds are more of vertical in nature during the pre-monsoon season and mostly come up during late afternoon and early evening hours. They are triggered by high temperature, low-level moisture, conditional instability, etc., and towering clouds build up. Premonsoon showers are accompanied sometimes by squally winds leading to dust storms and they are patching in nature (https://meteorologicalconsulta nt.wordpress.com/2017/04/09/difference-betweenmonsoon-and-pre-monsoon-rain/).

From the agricultural point of view the premonsoon rainfall is beneficial for mango, jute, rice and tea cultivation in West Bengal. In urban area, though it has some hazardous effects such as flooding, lightning, strong wind, hail, water logging, etc., it gives temporary comfort to people during the summer. Analysis of monthly or yearly rainfall is widely used in various applications regarding real-time monitoring of flood events, different climatic model diagnosis and verification (Janowiak and Arkin 1991) to study the changes in climate due to urbanisation, and in the field of energy budgeting (WCRP 1993; Narkhedkar et al. 2010).

Over the last 50 yrs, rapid development of urbanisation throughout the world has caused significant socio-economic and environmental degradation. Population has increased from 5\% to $90 \%$ today in different urbanised sectors and almost two third of the total population is supposed to live in the developing region in the middle of 21st century (Maktav et al. 2005). In West Bengal, the scenario is almost the same. Destruction of local forests for developing different layers of human habitation is the main part of urbanisation, which shapes the urban canopy and modifies the radiation also. When a land cover is transformed into an urban area, the region will be quite different from the surroundings due to changes in thermal and dynamical characteristics of the underlying surface. Around the globe the urban regions are found to be warmer than the surrounding rural area. Urban regions, cited as the main source of anthropogenic atmospheric pollution (Landsberg 1962), have large and significant impact on a local scale including changes in atmospheric composition, surface humidity, cloud formation and precipitation (UNFP 1999). These in turn influence the microclimate to a large extent (Tahir et al. 2014). India is an agrarian country and the economy is totally dependent upon seasonal precipitation. In addition, the amount of rainfall also fulfils various industrial as well as human necessities.

Like any other rapidly developing country India also experiences urbanisation effect on its rainfall. Urbanisation effect on pre-monsoon rainfall in some cities of the eastern part of India during pre- and post-independence years were investigated by Mitra et al. (2012). The study revealed that nearly $50 \%$ of land cover increased in the East Gangetic plain during the post-independence period. A rainfall trend analysis using non-parametric Mann-Kendall test shows that the rainfall trend significantly increased for the urbanised stations and non-significant trend is found for less urbanised downwind stations in the period 1950-2000 (Mitra et al. 2012). The impact of urbanisation on natural precipitation was studied in various regions around the globe by various researchers. Huff and Changnon (1972) investigated the urbanisation effect on the natural precipitation distribution over St. Louis by using the radar climatological studies. The result reveals that an increase in average summer precipitation ranging from $6 \%$ to $15 \%$ is caused by urbanisation. Inoue and Kimura (2004) reported that low-level cloud frequency in summer days was higher in the urban region than the rural area over Tokyo. Variability in average diurnal summer rainfall distribution in pre- and post-urban period in Houston metropolitan area was studied by Burian and Marshall (2005). They found that average summer rainfall distribution was more significant in post-urban period. Meng et al. (2007) showed that due to the combined effect of urbanisation and urban heat island intensity, the amount of precipitation increased in Guangzhou city. According to Rose 
et al. (2008) cloud to ground lightning flashes and precipitation were increased in warm season over Atlanta, Georgia (United States) due to the effect of urbanisation. Ganeshan et al. (2013) also analysed the effect of urban heat island on warm season precipitation in some US cities such as Minneapolis, Washington DC, New York City, Providence, Cleveland, Dallas and Houston. They found that rainfall anomalies were the highest during afternoon in most of the cities but in coastal urban areas these anomalies were the highest during daytime.

\section{Objective of the study}

The present work aims at a comparison of yearly pre-monsoon rainfall for two meteorological stations of Kolkata, namely Dumdum and Alipore during the period 1970-2014. As Alipore station is situated in the core region of Kolkata, this region has not undergone great transformation during this urbanisation period, but the situation is completely different in case of Dumdum. Initially, the station was located in a rural to semi-urban region; but over the years, it has experienced rapid urbanisation. Dumdum is still in transitional phase. So, it is interesting to compare the precipitation in these two places during this transitional period.

From the satellite images of Kolkata region it is shown that during the past decades this region has experienced a huge change in the case of land-use pattern as well as change of low surface temperature of Kolkata.

\section{Data}

The daily rainfall data of Dumdum and Alipore for the pre-monsoon period (March, April and May) during the years 1970-2014 are collected from the Regional Meteorological Centre, Indian Meteorological Department, Alipore. The geographical images are collected from different government and non-government organisations (NATMO (National Atlas and Thematic Mapping Organization), Govt. of India, The National Survey and Mapping Organization of the country under the Department of Science \& Technology and CAD Jadavpur University).

\section{Methodology}

In the literature all the symbols used in the statistical analysis have their usual meanings.
To analyse the collected rainfall data relevant quantitative and qualitative statistical techniques are used. The geographical analysis is performed

\begin{tabular}{|c|c|c|}
\hline Year & Dumdum & Alipore \\
\hline 1970 & 165 & 176 \\
\hline 1971 & 356 & 339 \\
\hline 1972 & 36 & 24 \\
\hline 1973 & 208 & 395 \\
\hline 1974 & 306 & 291 \\
\hline 1975 & 87 & 142 \\
\hline 1976 & 224 & 219 \\
\hline 1977 & 281 & 233 \\
\hline 1978 & 325 & 296 \\
\hline 1979 & 83 & 133 \\
\hline 1980 & 237 & 227 \\
\hline 1981 & 557 & 437 \\
\hline 1982 & 267 & 221 \\
\hline 1983 & 358 & 664 \\
\hline 1984 & 190 & 167 \\
\hline 1985 & 171 & 135 \\
\hline 1986 & 191 & 204 \\
\hline 1987 & 268 & 205 \\
\hline 1988 & 175 & 158 \\
\hline 1989 & 128 & 50 \\
\hline 1990 & 361 & 455 \\
\hline 1991 & 107 & 150 \\
\hline 1992 & 264 & 118 \\
\hline 1993 & 318 & 283 \\
\hline 1994 & 315 & 199 \\
\hline 1995 & 242 & 97 \\
\hline 1996 & 107 & 106 \\
\hline 1997 & 175 & 149 \\
\hline 1998 & 378 & 329 \\
\hline 1999 & 160 & 242 \\
\hline 2000 & 346 & 360 \\
\hline 2001 & 377 & 315 \\
\hline 2002 & 338 & 157 \\
\hline 2003 & 450 & 389 \\
\hline 2004 & 143 & 154 \\
\hline 2005 & 303 & 284 \\
\hline 2006 & 282 & 158 \\
\hline 2007 & 124 & 226 \\
\hline 2008 & 256 & 186 \\
\hline 2009 & 380 & 273 \\
\hline 2010 & 199 & 175 \\
\hline 2011 & 275 & 174 \\
\hline 2012 & 231 & 229 \\
\hline 2013 & 229 & 163 \\
\hline 2014 & 148 & 152 \\
\hline
\end{tabular}


Table 2. ANOVA.

\begin{tabular}{lcrrrrr}
\hline Source of variation & SS & df & MS & $F$ & $P$ value & $F_{\text {crit }}$ \\
\hline Between groups & 16187.21 & 1 & 16187.21 & 1.542583 & 0.217534 & 3.949321 \\
Within groups & 923434.8 & 88 & 10493.58 & & & \\
Total & 939622.1 & 89 & & & & \\
\hline
\end{tabular}

$F=$ computed $F$ ratio.

$F_{\text {crit }}=$ critical $F$ value at $5 \%$ level of significance.

using geographic information system technique. The statistical part is more highlighted in the current study.

The statistical analysis is performed for annual pre-monsoon rainfall (section 4.1) as well as average annual pre-monsoon rainfall (section 4.2) at Dumdum and Alipore during the period 19702014.

\subsection{Statistical analysis for annual pre-monsoon rainfall at Dumdum and Alipore}

- The data set of annual pre-monsoon rainfall over Dumdum and Alipore used for this study is given in table 1.

- Analysis of variance (ANOVA) test is applied to the data sets of annual pre-monsoon rainfall at Dumdum and Alipore during (1970-2014) to check if there is an association present between them (table 2).

- Scatter diagrams are drawn to get an idea of the relationship, not causal, between the annual rainfall at Dumdum and Alipore during the periods 1970-2014, 1970-1990 and 1991-2014 (figure 1).

- Pearson correlation coefficients $(R)$ are computed for the three periods 1970-2014, 19701990 and 1991-2014 of the study and the significance tests for $R$ is performed using $t$ statistic, where $t=R / S_{R}, S_{R}=\sqrt{\left(1-R^{2} / N-2\right)}, n$ being the total number of observations and $S_{R}$ is the standard deviation (table 3).

- Regression lines are fitted to the data of study period using the principle of least squares (figure 2) to predict the annual pre-monsoon rainfall at Dumdum on the basis of that at Alipore and vice versa. The corresponding graphs for comparison of the actual and predicted annual pre-monsoon rainfall are given in figures 3 and 4 .

- Since some changes are noted to occur regarding urbanisation especially at Dumdum from 1990, an attempt is made to explore if there is any change in pre-monsoon rainfall trend over the area of study during this period. That is why the total period 1970-2014 is subdivided into two periods, i.e., pre-urbanisation (1970-1990) and post-urbanisation (1991-2014) and the following statistical analysis is performed.

- 95\% confidence intervals for means and standard deviations of annual pre-monsoon rainfall for the relevant cases are constructed (tables 4 and 5).

- The coefficients of variations (relative measures of dispersion) of annual pre-monsoon rainfall over Dumdum and Alipore for the periods 1970 2014, 1970-1990 and 1991-2014 are calculated (table 6) and shown in figure 5.

\subsection{Statistical analysis for annual average pre-monsoon rainfall at Dumdum and Alipore}

- The multiple vertical bar diagrams of annual average pre-monsoon rainfall are drawn for the periods 1970-2014, 1970-1990 and 1991-2014 (figure 6).

- The corresponding quantified values are given in table 7 .

- The Wilcoxon Signed Rank Sum test, a nonparametric or distribution free test is used:

(a) to test the null hypothesis that the average annual pre-monsoon rainfall of Alipore and Dumdum is statistically equal;

(b) to find the probability of observing the value of $Z_{0}$ (the test statistic).

- Basic features of Wilcoxon Signed Rank Sum test used in the literature are discussed below (Goon et al. 1975 and http://statweb.stanford.

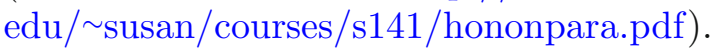

We have two independent continuous variables $X_{i}$ (annual average pre-monsoon rainfall at Dumdum) and $Y_{i}$ (annual average pre-monsoon rainfall at Alipore), where $i=1,2,3$. It is assumed that the distributions of $X_{i}$ and $Y_{i}$ have the same shape and spread. The Wilcoxon Signed Rank Sum test can be used to test the null hypothesis, $\mathrm{H}_{0}: X_{i}=Y_{i}$ at $5 \%$ significance level. 
(a) $1970-2014$

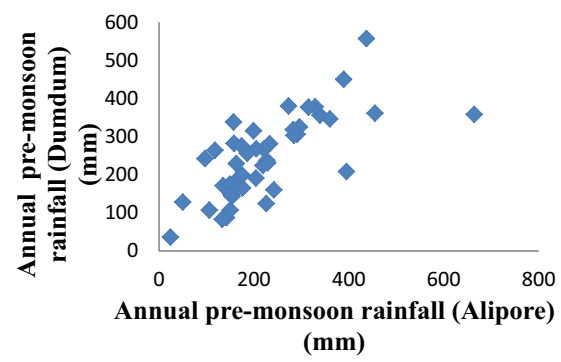

(c) $1991-2014$

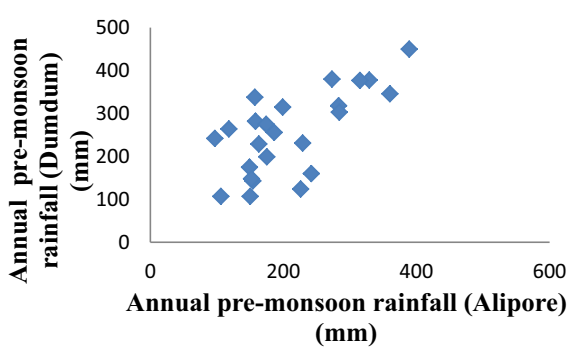

(e) $1970-1990$

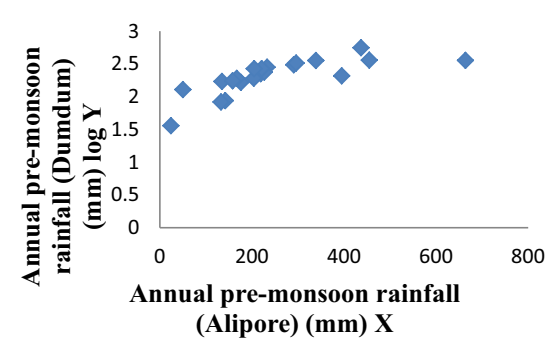

(g) 1970-2014

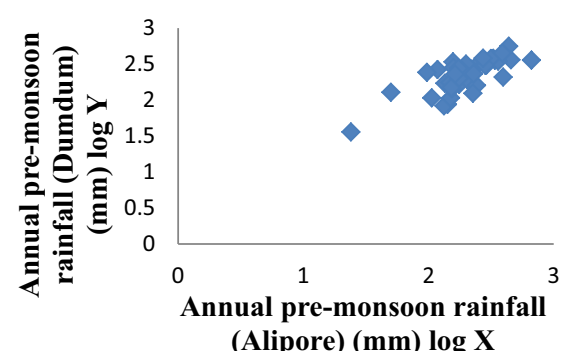

(Alipore) (mm) $\log X$ (b) $1970-1990$

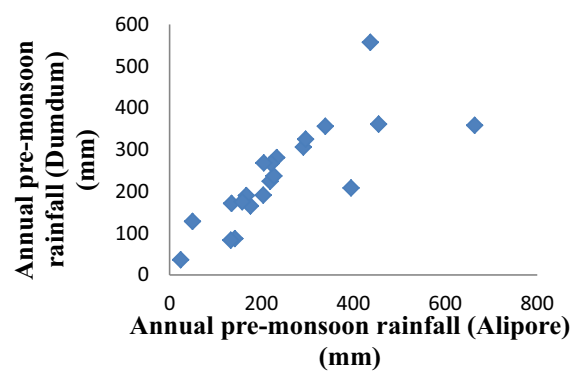

(d) 1970-2014

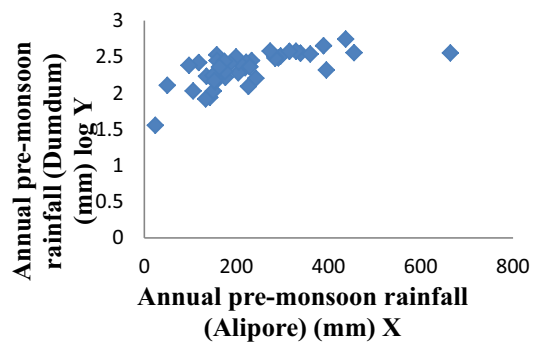

(f) 1991-2014

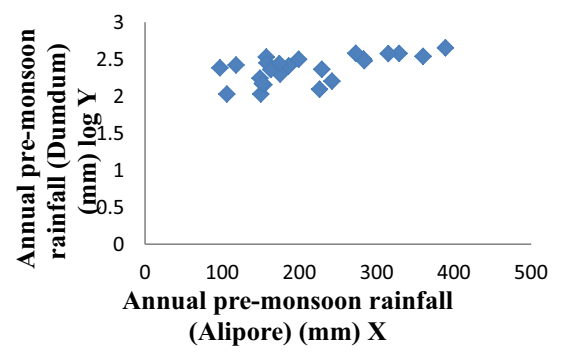

(h) $1970-1990$

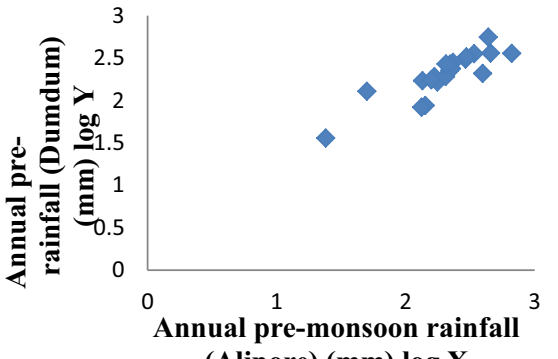

(Alipore) $(\mathrm{mm}) \log \mathrm{X}$

(i)1991-2014

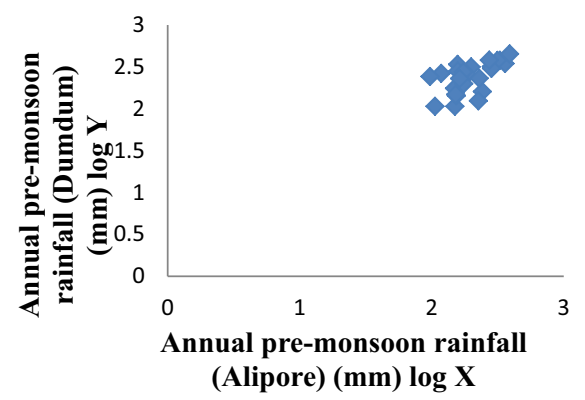

Figure 1. Scatter diagrams of annual pre-monsoon rainfall during three periods 1970-2014, 1970-1990 and 1991-2014 over Dumdum and Alipore. (i) Alipore $(X)$ vs. Dumdum $(Y)$ (a) 1970-2014, (b) 1970-1990, and (c) 1991-2014, (ii) Alipore (X) vs. Dumdum $(\log Y)$, (d) 1970-2014, (e) 1970-1990, and (f) 1991-2014, (iii) Alipore (log $X)$ vs. Dumdum (log $Y$ ) (Dumdum), (g) 1970-2014, (h) 1970-1990, and (i) 1991-2014. 
Table 3. Correlation coefficients and their significance tests for annual pre-monsoon rainfall (mm) over Dumdum and Alipore for the three periods (1970-2014), (1970-1990), and (19912014).

\begin{tabular}{lcccc}
\hline Period & $\begin{array}{c}\text { Correlation } \\
\text { coefficients }\end{array}$ & $R^{2}$ & $t_{\text {computed }}$ & $5 \%$ significance level \\
\hline $1970-2014$ & 0.71 & 0.50 & 6.45 & 2.017 \\
$1970-1990$ & 0.78 & 0.64 & 8.79 & 2.101 \\
$1991-2014$ & 0.69 & 0.48 & 6.27 & 2.074 \\
\hline
\end{tabular}

(a) $1970-2014$

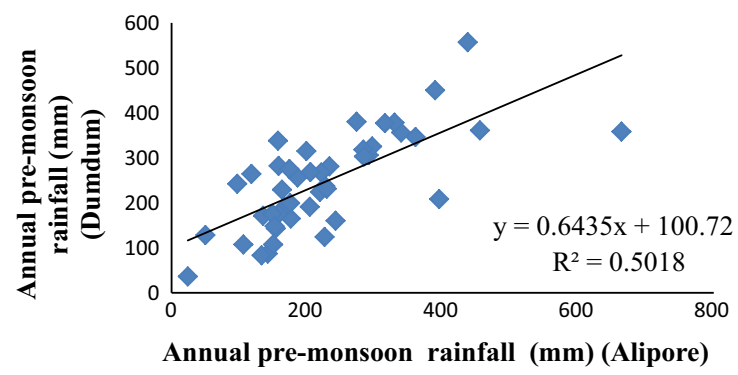

(b) $1970-1990$

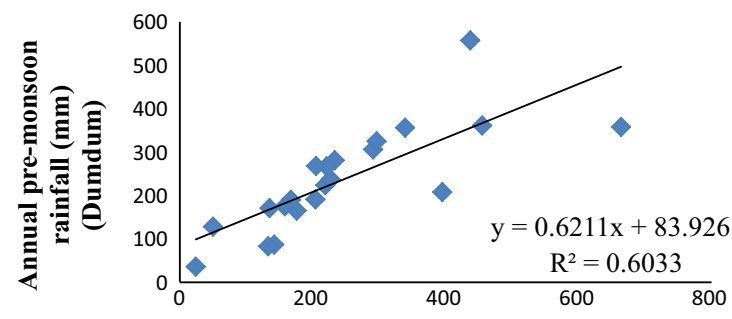

Annual pre-monsoon rainfall (mm) (Alipore)

(c) 1991-2014

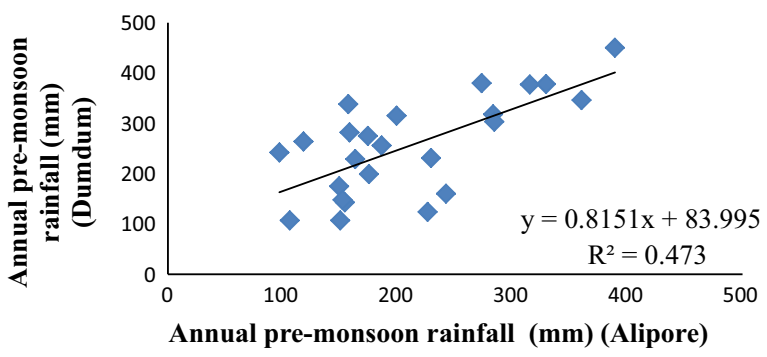

(d) 1970-2014

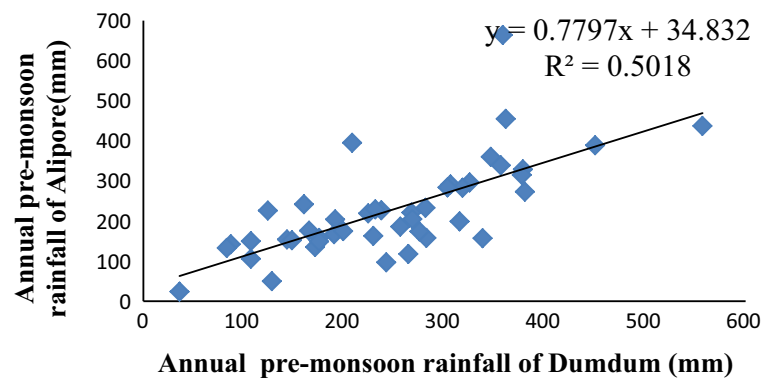

(e) $1970-1990$

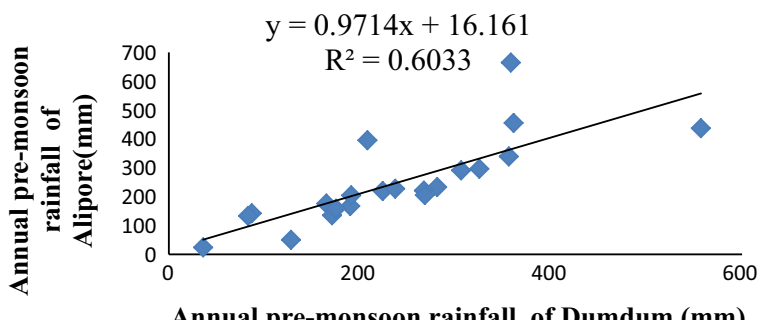

(f) $1991-2014$

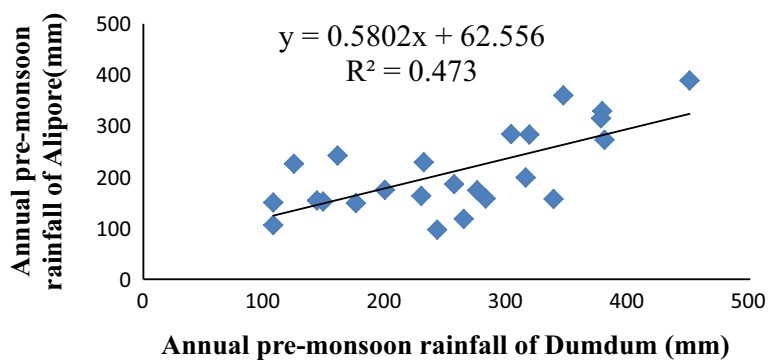

Figure 2. Regression lines for annual pre-monsoon rainfall (mm) during three periods 1970-2014, 1970-1990 and 1991-2014: (i) regression lines for annual pre-monsoon rainfall (mm) of Dumdum on the basis of Alipore (a) 1970-2014, (b) 1970-1990, and (c) 1991-2014, (ii) regression lines for annual pre-monsoon rainfall ( $\mathrm{mm}$ ) of Alipore on the basis of Dumdum (d) 1970-2014, (e) 1970-1990, and (f) 1991-2014.

Under the null hypothesis, one would expect the distribution of the differences to be approximately symmetric around zero and the distribution of positives and negatives to be distributed at random among the ranks. Under this assumption, it is possible to work out the exact probability of every possible outcome for $Z_{0}$ (the test statistic), Here, $W^{+}$is the sum of the ranks of the positive $\mathrm{d} i$ 's, $W^{-}$is the sum of the ranks of the negative $\mathrm{d} i$ 's, where $\mathrm{d} i$ (paired difference) $=X_{i}-Y_{i}$, where $X_{i}, Y_{i}$ are the pairs of observations and $i=1,2,3$ for three periods. 

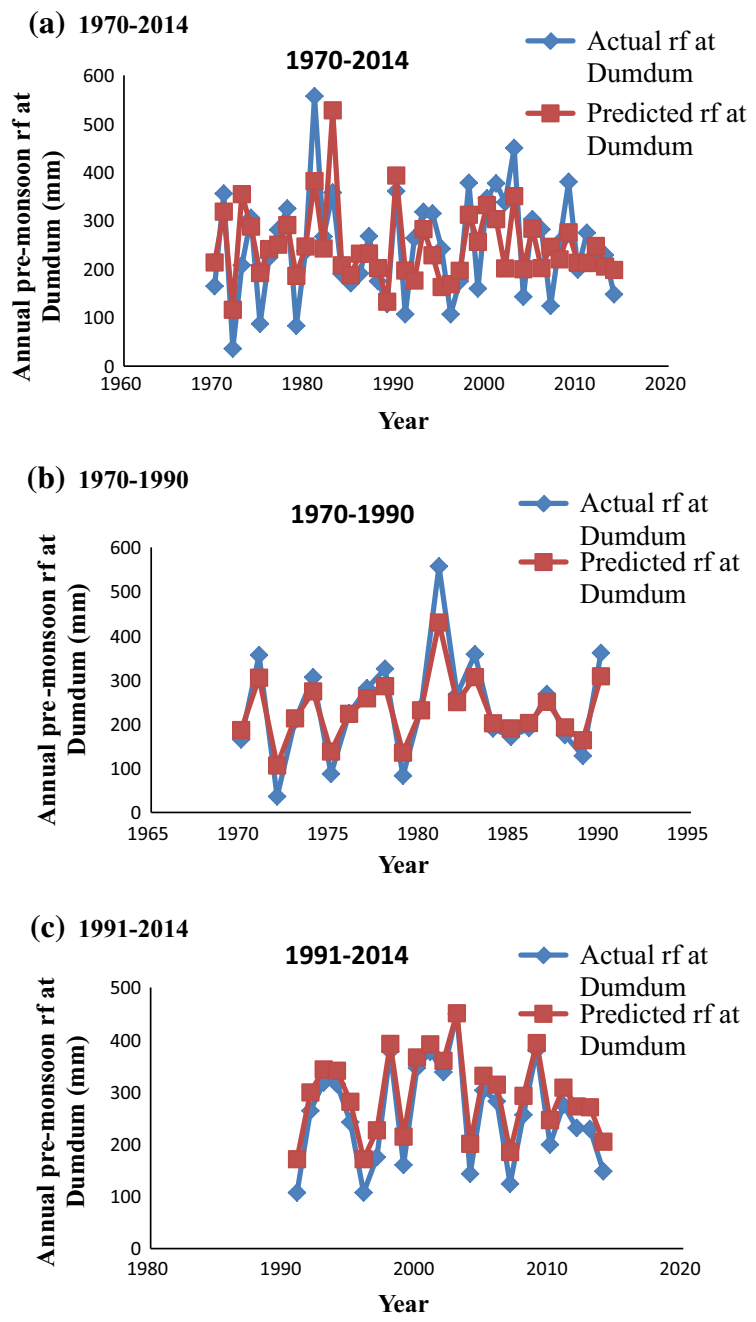

Figure 3. Comparison of actual and predicted (on the basis of Alipore) annual pre-monsoon rainfall at Dumdum during three periods 1970-2014, 1970-1990, and 1991-2014.

As a check, the total $\left(W^{+}+W^{-}\right)$should be equal to $n(n+1) / 2$, where $n$ is the number of pairs of observations in the sample. Here,

$$
W=\operatorname{Min}\left(W^{+}, W^{-}\right),
$$

$W^{*}{ }_{\text {critical }(0.05)}=$ critical value of $W$ at $5 \%$ significance level:

$$
Z_{0}=\frac{W-n(n+1) / 4}{\sqrt{n(n+1)(2 n+1) / 24}}
$$

where $Z_{0}$ is approximately standard normal when $n$ is large.

If $W \leq W^{*}{ }_{0.05}$, then null hypothesis is rejected. If $W>W^{*}{ }_{0.05}$, then null hypothesis is accepted.

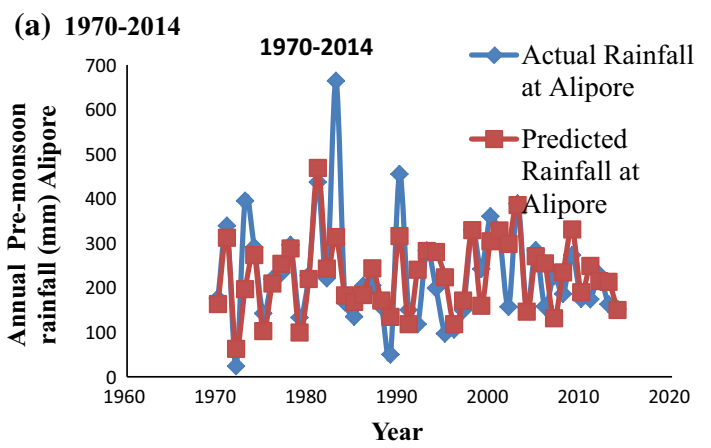

(b) $1970-1990$

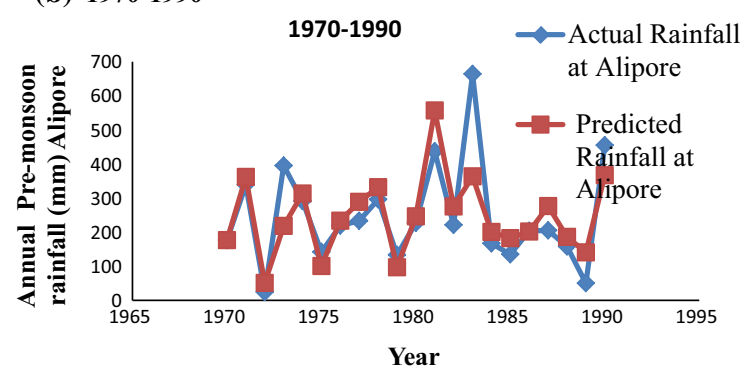

(c) 1991-2014

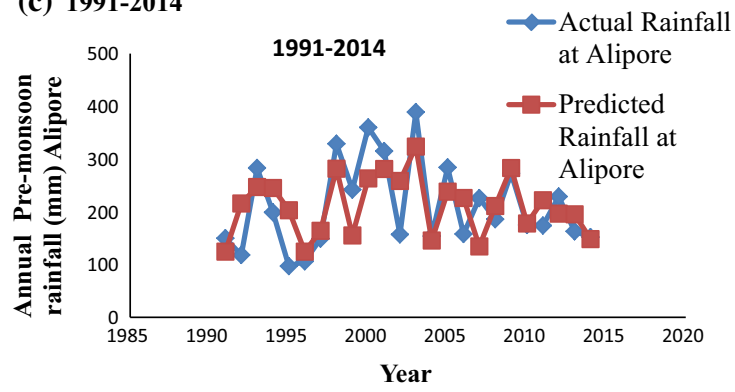

Figure 4. Comparison of actual and predicted (on the basis of Dumdum) annual pre-monsoon rainfall at Alipore during three periods 1970-2014, 1970-1990, and 1991-2014.

- The test results for annual average pre-monsoon rainfall at Dumdum and Alipore based on the $W$ statistic are given in table 8 .

- Tables of critical probability values of Wilcoxon Signed Rank Sum test are shown based on the approximate $Z_{0}$ statistic used to find the probability of observed value of $Z_{0}$. Lower range of observed probability is more significant in nature (table 9).

\section{Results and discussions}

The results of the annual pre-monsoon rainfall and average annual pre-monsoon rainfall at Dumdum and Alipore are discussed in separate sections 5.1 and 5.2 , respectively. 
Table 4. 95\% confidence intervals for mean of annual pre-monsoon rainfall (mm) over Dumdum and Alipore.

\begin{tabular}{lcrrr}
\hline Year & Dumdum & Length & Alipore & Length \\
\hline 1) $1970-2014$ & $(212.16,277.84)$ & 65.68 & $(191.9,252.1)$ & 60.2 \\
2) $1970-1990$ & $(181.89,292.11)$ & 110.22 & $(177,285.2)$ & 108.2 \\
3) $1991-2014$ & $(210.29,295.71)$ & 85.42 & $(175.6,246.4)$ & 70.8 \\
\hline
\end{tabular}

Table 5. 95\% confidence intervals for standard deviations (SD) of annual pre-monsoon rainfall ( $\mathrm{mm}$ ) over Dumdum and Alipore.

\begin{tabular}{llccr}
\hline Year & Dumdum & Length & Alipore & Length \\
\hline 1) $1970-2014$ & $(89.50,140.3)$ & 50.08 & $(81.93,128.50)$ & 46.57 \\
2) $1970-1990$ & $(92.51,180.75)$ & 88.24 & $(90.93,177.68)$ & 86.75 \\
3) $1991-2014$ & $(76.71,145.02)$ & 68.31 & $(64.84,123)$ & 58.16 \\
\hline
\end{tabular}

Table 6. Values of coefficients of variation of annual premonsoon rainfall ( $\mathrm{mm}$ ) over Dumdum and Alipore during the period (1970-2014), (1970-1990), and (1991-2014).

\begin{tabular}{lcc}
\hline Year & $\begin{array}{c}\text { Annual pre-monsoon } \\
\text { rainfall over } \\
\text { Dumdum }(\mathrm{mm})\end{array}$ & $\begin{array}{c}\text { Annual pre-monsoon } \\
\text { rainfall over } \\
\text { Alipore }(\mathrm{mm})\end{array}$ \\
\hline $1970-2014$ & 43.32 & 50 \\
$1970-1990$ & 50 & 60 \\
$1991-2014$ & 38 & 39 \\
\hline
\end{tabular}

\subsection{Results and discussions for annual} pre-monsoon rainfall at Dumdum and Alipore

- It is noted from ANOVA that $F$ value $<F_{\text {critical }}$. This implies that the overall annual pre-monsoon rainfall at Dumdum and Alipore during the period 1970-2014 does not differ so far as this sample is concerned. But the $P$ value indicates that the result is not significant at $5 \%$ level (table 2).

- The scatter diagrams of $X$ vs. $\log Y$ (figure $1 \mathrm{~d}-\mathrm{f}$ ) and $\log X$ vs. $\log Y$ (figure $1 \mathrm{~g}-\mathrm{i}$ ) do not show any linear relationship, whereas that of $X$ vs. $Y$ suggests a linear fit between $X$ and $Y$ (figure $1 \mathrm{a}-\mathrm{c}$ ), where $X$ and $Y$ denote the annual pre-monsoon rainfall over Alipore and Dumdum, respectively, during the three periods 1970-2014, 1970-1990 and 1991-2014.

- The significance tests for $R$ 's reveal that in each case the correlation coefficient is significant at $5 \%$ level. For the period $1970-2014 R^{2}$ value shows that $50 \%$ of the total variance of one variable may be associated with the variance of the other. During the period 1970-1990 $R^{2}$ value showed that $64 \%$ of the total variance of one variable may be associated with the variance of the

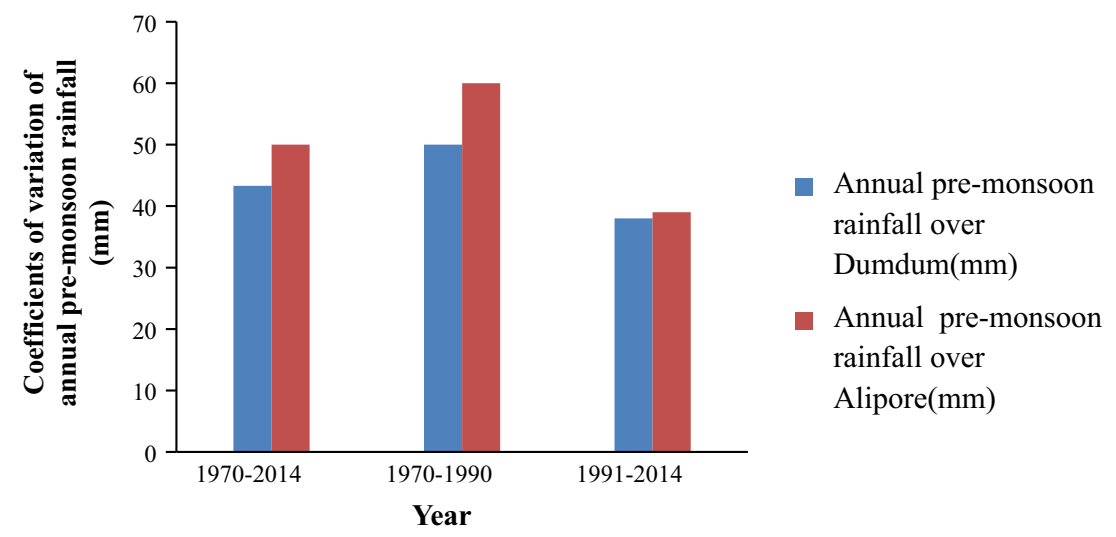

Figure 5. Coefficients of variation of annual pre-monsoon rainfall ( $\mathrm{mm}$ ) over Dumdum and Alipore during the period 1970-2014, 1970-1990, and 1991-2014. 


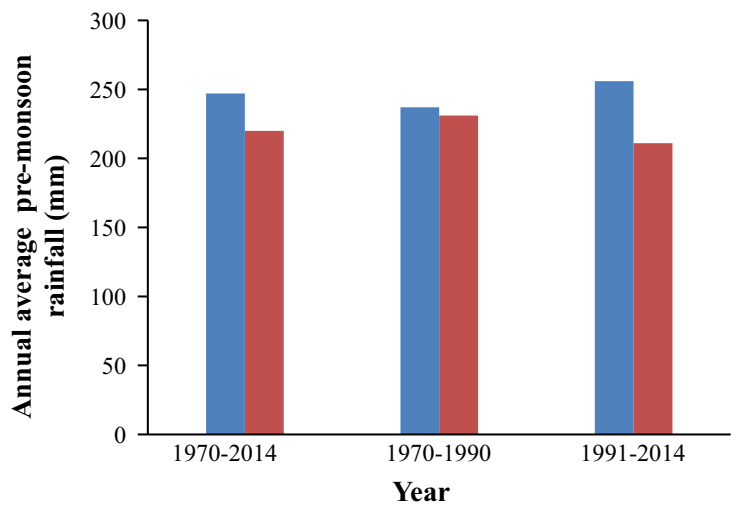

- Annual average premonsoon rainfall over Dumdum(mm)

- Annual average premonsoon rainfall over Alipore(mm)

Figure 6. Annual average pre-monsoon rainfall (mm) over Dumdum and Alipore during the periods 1970-2014, 1970-1990, and 1991-2014.

other and during the period 1991-2014 $R^{2}$ value shows that $48 \%$ of the total variance of one variable may be associated with the variance of the other (table 3).

It is to be observed from the values of $R$ that in post-urbanisation period the correlation coefficient between the two series of annual pre-monsoon rainfall at Dumdum and Alipore is less than that in pre-urbanisation period. So it may be stated that in post-urbanisation period the correlation between the annual pre-monsoon rainfall at Dumdum and Alipore becomes weaker. The regression lines are fitted, so that if the amount of annual pre-monsoon rainfall at one station is known, but that at the other (station) is missing or unreliable, then the

Table 7. Quantified annual average pre-monsoon rainfall ( $\mathrm{mm}$ ) over Dumdum and Alipore during the periods (19702014), (1970-1990), and (1991-2014).

\begin{tabular}{lcc}
\hline & $\begin{array}{c}\text { Annual average } \\
\text { pre-monsoon } \\
\text { rainfall over } \\
\text { Dumdum }(\mathrm{mm})\end{array}$ & $\begin{array}{c}\text { Annual average } \\
\text { pre-monsoon } \\
\text { rainfall over } \\
\text { Ylipore }(\mathrm{mm})\end{array}$ \\
\hline $1970-2014$ & 247 & 220 \\
$1970-1990$ & 237 & 231 \\
$1991-2014$ & 256 & 211 \\
\hline
\end{tabular}

most probable value of the same may be estimated or predicted within the range.

- The regression lines and $R^{2}$ values are given in figure 2 .

- From the satellite images of changing pattern of land use of Kolkata during 1989-2010, it is noticed that settlement is becoming more denser in the period 2006-2010 (figure 7) (Sharma and Chakraborty 2015).

- The satellite images of the growth of urban built area in Kolkata during the period 1980 2010 depicts that the urban growth is more at Dumdum (North 24 PGS) than at Alipore (South 24 PGS) (figure 8).

Table 9. Critical probability values of Wilcoxon Signed Rank Sum test is shown based on the approximate $Z_{0}$ statistic used to find the probability of observed value of $Z_{0}$.

\begin{tabular}{lcrcc}
\hline Year & $W^{+}$ & $W^{-}$ & $\left|Z_{0}\right|$ & $P$ \\
\hline $1970-2014$ & 763 & 268 & 2.821 & 0.003 \\
$1970-1990$ & 153 & 77 & 1.336 & 0.099 \\
$1991-2014$ & 239 & 61 & 2.542 & 0.006 \\
\hline
\end{tabular}

$P$ value $>0.05$ (not significant) $P$ value $<0.05$ (significant).

Table 8. Non parametric Wilcoxon Signed Rank Sum test for annual average pre-monsoon rainfall (mm) over Dumdum 8 Alipore.

\begin{tabular}{lrrrccc}
\hline Year & $W^{+}$ & $W^{-}$ & $W$ & $W_{\text {critical(0.05) }}^{*}$ & Results & $\begin{array}{c}\text { Inference } \\
\text { about } \mathrm{H}_{0}\end{array}$ \\
\hline $1970-2014$ & 763 & 268 & 268 & 343 & $\mathrm{~W}<\mathrm{W}_{\text {critical(0.05) }}^{*}$ & Rejected \\
$1970-1990$ & 153 & 77 & 77 & 58 & $\mathrm{~W}>\mathrm{W}_{\text {critical(0.05) }}^{*}$ & Accepted \\
$1991-2014$ & 239 & 61 & 61 & 81 & $\mathrm{~W}<\mathrm{W}_{\text {critical(0.05) }}^{*}$ & Rejected \\
\hline
\end{tabular}




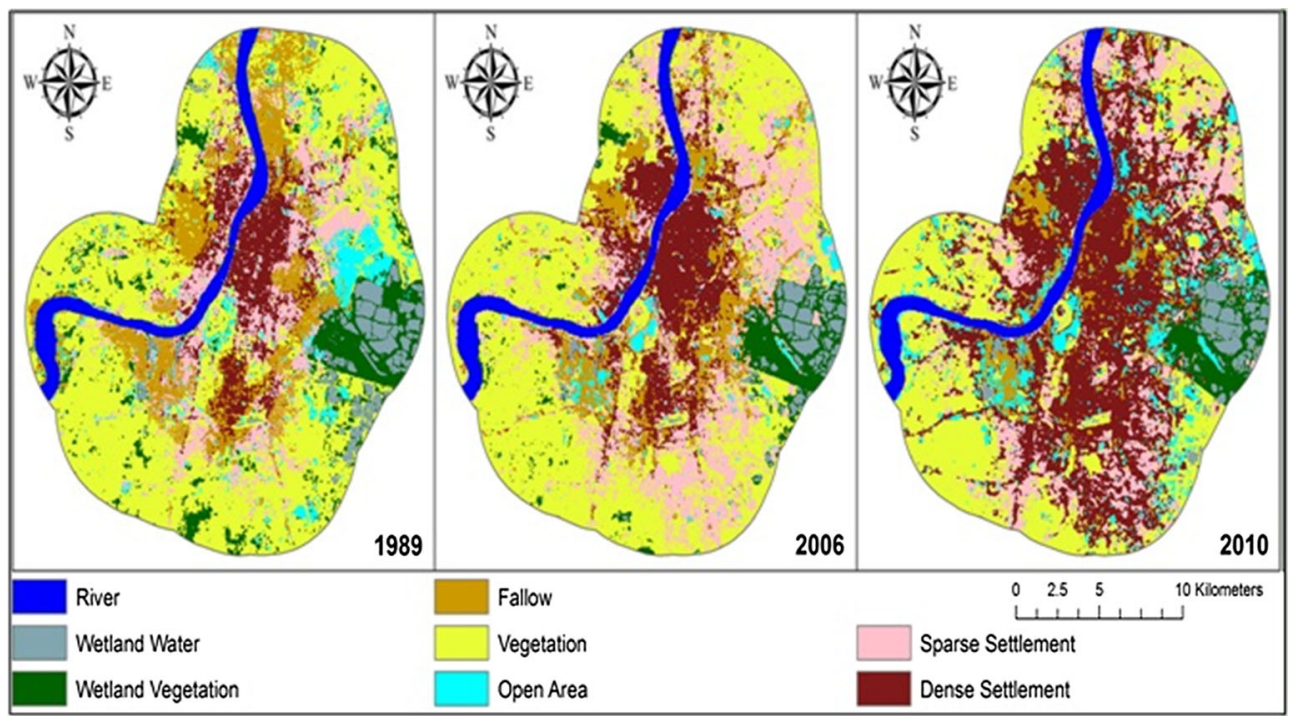

Changing Pattern of Landuse of Kolkata (1989-2010)

(Source: $R$. Sharma \& A. Chakraborty)

Figure 7. Changing pattern of land use of Kolkata (1989-2010) (source: Sharma and Chakraborty 2015).

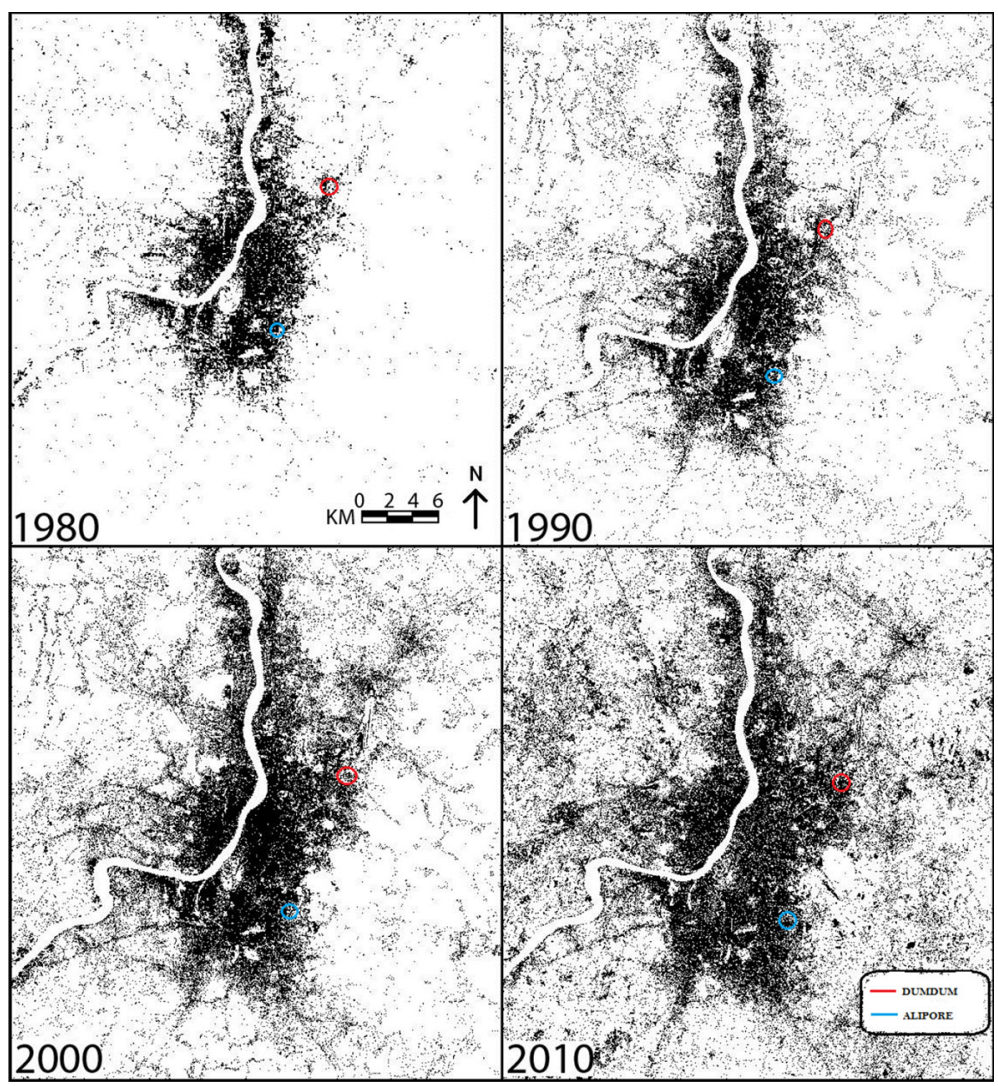

Figure 8. Urban growth of Kolkata during 1970-2010, red colour indicates Dumdum area and blue colour indicates Alipore area (source: Earth Observation Center (DLR-DFD)).

- The growth diagram of urban built area in Kolkata during 1970-2010 shows that the urban built area $\left(\mathrm{km}^{2}\right)$ increases almost 4.5 times during this time span (figure 9).
- The satellite images of the change of low surface temperature of Kolkata during the period 1989-2010 shows that surface temperature increases more in the period 
2006-2010 (figure 10) (Sharma and Chakraborty 2015).

- $95 \%$ confidence intervals for means of the annual pre-monsoon rainfall during the periods 19701990 and 1991-2014 for Dumdum and Alipore are less overlapping than that for the period 1970-1990 (table 4).

- Though the lengths of the $95 \%$ confidence intervals for the standard deviations of annual premonsoon rainfall over Dumdum and Alipore during the periods 1970-2014 and 1991-2014 are comparatively smaller than that of 1970-1990, it may be inferred that the annual pre-monsoon rainfall over Dumdum and Alipore is overall scattered in nature (table 5).

- Regarding the coefficients of variation of annual pre-monsoon rainfall at Dumdum and Alipore, it may be noticed that they are almost of the same nature in all the three periods (table 6

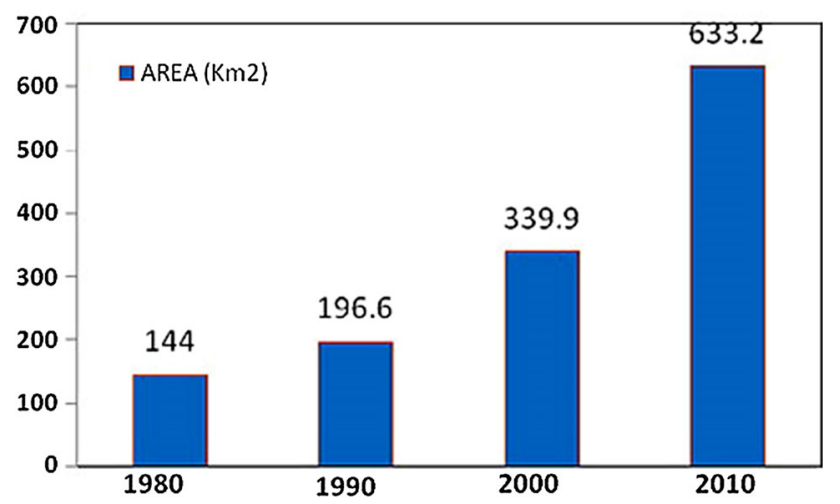

Figure 9. Growth of urban built area in Kolkata (19702010). and figure 5). The reasons may be the variability of some climatic conditions which are yet to be explored. But since the coefficients of variation of annual pre-monsoon rainfall over Dumdum are seen to be always less than that of Alipore throughout the time span of the study, it may be concluded that the data set of Dumdum shows less variability than that of Alipore.

\subsection{Results and discussions for annual average pre-monsoon rainfall at Dumdum and Alipore}

- The vertical bar diagrams of annual average pre-monsoon rainfall at Dumdum and Alipore during the periods 1970-2014, 1970-1990 and 1991-2014 are consistent with the results of non-parametric Wilcoxon Signed Rank Sum test which indicates that the annual average rainfall at Dumdum is always more than that of Alipore. But the annual average pre-monsoon rainfall at Dumdum has increased significantly than that of Alipore in the post-urbanisation period (table 7 and figure 6).

- The observations from the non-parametric Wilcoxon Signed Rank Sum test for Dumdum and Alipore (tables 8 and 9) are as follows:

a) During 1970-2014 the null hypothesis is rejected, so there is a significant difference present between mean annual pre-monsoon rainfall or annual average pre-monsoon rainfall of Dumdum and Alipore and the $P$ value in this period is significant at 5\% level and shows that the mean annual pre-monsoon

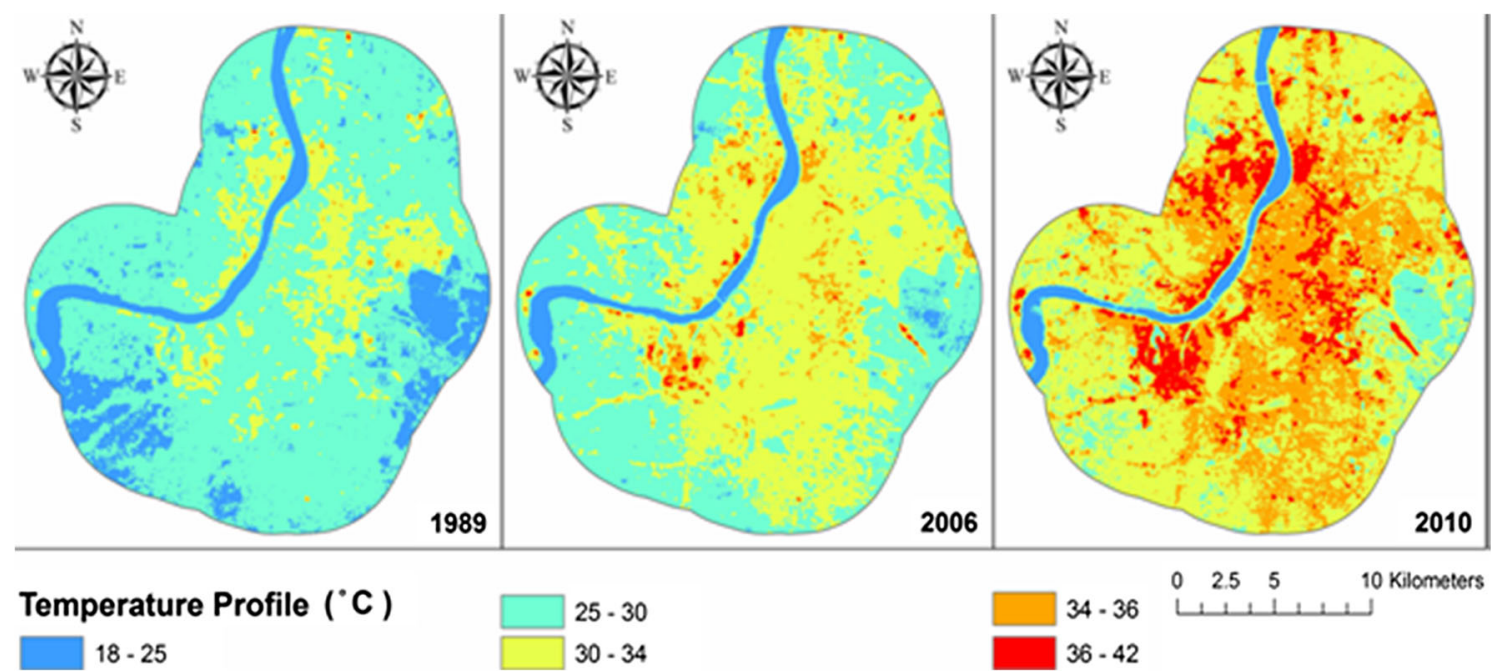

Figure 10. Change of low surface temperature of Kolkata (1989-2010) (source: Sharma and Chakraborty 2015). 
rainfall or annual average pre-monsoon rainfall is more at Dumdum than at Alipore.

b) During 1970-1990 the null hypothesis is accepted, so there is no difference present between mean annual pre-monsoon rainfall or annual average pre-monsoon rainfall at Dumdum and Alipore though the $P$ value in this period is not significant at $5 \%$ level of significance and shows that the mean annual pre-monsoon rainfall or annual average premonsoon rainfall is more at Dumdum than at Alipore.

c) During 1991-2014 the null hypothesis is rejected, so there is a significant difference present between mean annual pre-monsoon rainfall or annual average pre-monsoon rainfall of Dumdum and Alipore and the $P$ value in this period is significant at 5\% level and shows that the mean annual pre-monsoon rainfall or annual average pre-monsoon rainfall is more at Dumdum than at Alipore and this nature is reflected during the total period 1970-2014 too.

\section{Conclusion}

This work indicates that urbanisation has some effects on the annual average pre-monsoon rainfall at the outer periphery of Kolkata. The ANOVA reveals that the annual pre-monsoon rainfall over Dumdum and Alipore do not differ as far as the present data set is concerned, which indicates a homogeneous relationship in annual pre-monsoon rainfall between the regions during the period of study. Not only that there always exists a positive linear relationship between the annual pre-monsoon rainfall over Dumdum and Alipore, though the value of correlation coefficient is less in post-urbanisation period than that in preurbanisation period, it is also interesting to observe that the annual average pre-monsoon rainfall at Dumdum is always greater than that at Alipore. However, during the post-urbanisation period in the study the amount of annual average premonsoon rainfall increases at Dumdum, the greater Kolkata region, while it decreases at Alipore, the core area of Kolkata. This may be due to a developing and unstable situation over Dumdum region which is in transition from rural to semi-urban to urban region, whereas the situation is less transitional at Alipore.
From the satellite images it is found that the concepts of urbanisation, land-use change and change of low surface temperature are interrelated with each other. In addition, variability in rainfall is a related impact of urban land-use changes, where land-use change means the alteration of physical or natural landscape into artificial or manmade one. The present study reveals that the result of analysis from the statistical point of view is consistent with that from the geographical point of view - the urbanisation process affects the overall rainfall at Kolkata region and its outer periphery. But it is yet to be explored which parameters related to urbanisation are specifically responsible for that.

\section{Acknowledgements}

The authors are grateful to the Regional Meteorological Centre, India Meteorological Department, Alipore for the supply of necessary rainfall data. The authors are also indebted to the National Atlas and Thematic Mapping Organization, Survey of India, Government of India for providing the satellite data. The authors also acknowledge Computer Aided Centre, Jadavpur University, Kolkata 700032, India, for assistance.

\section{References}

Burian S J and Shepherd J Marshall 2005 Effect of urbanization on the Diurnal rainfall pattern in Houston; Hydrol. Process. 19 1089-1103, https://doi.org/10.1002/ Hyp.5647.

Chatterjee P, Pradhan D and De U K 2008 Simulation of local severe storm by mesoscale model MM5; Indian J. Radio Space Phys. 37 419-433.

Dore M H I 2005 Climate change and changes in global precipitation patterns: What do we know?; Environ. Int. 31 1167-1181, https://doi.org/10.1016/j.envint.2005.03.004.

Ganeshan M, Raghu M and Imhoff M L 2013 A multi-city analysis of the UHI-influence on warm season rainfall; Urban Clim. 6 1-123, https://doi.org/10.1016/j.uclim. 2012013.09.004.

Goon A M, Gupta M K and Dasgupta B 1975 Fundamental of statistics; The World Press Private Limited, 1 512-513.

Huff F A and Changnon S A 1972 Climatological assessment of urban effects on precipitation at St. Louis; J. Appl. Meteorol. 11 823-842; https://doi.org/10.1175/ 1520-450(1972)011<0823:CAOUEO > 2.0.CO;2.

Inoue T and Kimura F 2004 Urban effects on low-level clouds around the Tokyo metropolitan area on clear summer days; Geophys. Res. Lett. 31(L0) 5103; https://doi.org/ 10.1029/2003GL018908. 
Janowiak J E and Arkin P A 1991 Rainfall variations in the tropics during 1986-1989, as estimated from observations of cloud-top temperature; J. Geophys. Res. 96 3359-3373; https://doi.org/10.1029/90JD01856.

Kumar K K, Kumar K R and Pant G B 1997 Premonsoon maximum and minimum temperatures over India in relation to the summer monsoon rainfall; Int. J. Climatol. 17 1115-1127; https://doi.org/10.1002/ (SICI)1097-0088(199708)17:10<1115::AID-JOC182>3.0. $\mathrm{CO} ; 2-\mathrm{Z}$.

Kumar V, Jain S K and Singh Y 2010 Analysis of long-term rainfall trends in India; Hydrol. Sci. J. 55(4) 484-496; https://doi.org/10.1080/02626667.2010.481373.

Landsberg H E 1962 City air - better or worse; Air Over Cities, U.S. Public Health Service, Tech. Rept. A62-5, Cincinnati, pp. 1-22.

Maktav D, Erbek F S and Jurgens C J U 2005 Remote sensing of urban areas; Int. J. Remote Sens. 26(4) 655-659, https://doi.org/10.1080/01431160512331316469.

Meng W, Yan J H and Hu H 2007 Urban effects and summer thunderstorms in a tropical cyclone affected situation over Guangzhou city; Sci. China Ser. D 50 1867-1876, https://doi.org/10.1007/s11430-007-0142-5.

Mitra C, Shepherd J M and Jordanb T 2012 On the relationship between the premonsoonal rainfall climatology and urban land cover dynamics in Kolkata city, India; Int. J. Climatol. 32 1443-1454, https://doi.org/10.1002/ joc. 2366 .

Narkhedkar S G, Sinha S K and Mukhopadhyay P 2010 Rainfall analysis using conventional and non-conventional rainfall information on monthly scale; Atmósfera $\mathbf{2 3 ( 2 )}$ $141-164$.

Corresponding editor: A K SAHAI
New M, Todd M, Hulme M and Jones P 2001 Precipitation measurements and trends in the twentieth century; Int. J. Climatol. 21 1889-1922, https://doi.org/10.1002/ joc. 680 .

Rose L S, Stallins J A and Bentley M L 2008 Concurrent cloud-to-ground lightning and precipitation enhancement in the Atlanta, Georgia (USA) urban region; Earth Interact. 12 1-30, https://doi.org/10.1175/2008EI265.1.

Sahu K R and Khare D 2015 Spatial and temporal analysis of rainfall trend for 30 districts of a coastal state (Odisha) of India; Int. J. Geol., Earth Environ. Sci. 1 40-53.

Sharma R, Chakraborty A and Joshi P K 2015 Geospatial quantification and analysis of environmental changes in urbanizing city of Kolkata (India); Environ. Monit. Assess. 187 4206, https://doi.org/10.1007/ s10661-014-4206-7.

Tahir A A, Muhammad A, Mahmood Q, Ahmad S S and Ullah Z 2014 Impact of rapid urbanization on microclimate of urban areas of Pakistan; Air Qual. Atmos. Health 8 299-306

UNFP 1999 The state of world population 1999; United Nations Population Fund, United Nations Publications, New York, 76p.

World Climate Research Programme (WCRP) 1993 Global observations, analyses and simulation of precipitation; Rep. WCRP-78, WMO/TD 544, World Meteor. Org., Geneva, XXp.

http://statweb.stanford.edu/ susan/courses/s141/ hononpara.pdf.

https://meteorologicalconsultant.wordpress.com/2017/04/ 09/difference-between-monsoon-and-pre-monsoon-rain/. 